\title{
COMPARISON BETWEEN COOPERATIVE LEARNING METHODS AND PROBLEM BASED LEARNING USING PERSONAL LETTER IN TEACHING STUDENTS' ABILITY IN WRITING AT SMA SEBELAS MARET BANDUNG
}

\author{
Verawati $^{1}$, Wawan Kuswandi ${ }^{2}$ \\ ${ }^{1}$ IKIP Siliwangi \\ ${ }^{2}$ IKIP Siliwangi \\ ${ }^{1}$ selia.yorri13@gmail.com, ${ }^{2}$ wawankuswandi520@gmail.com
}

\begin{abstract}
The paper explains about the comparison between cooperative learning methods and problem based learning using personal letter in teaching students' ability in writing skill. Experiment study at SMA Sebelas Maret Bandung. The method of this research is experiment quasi concerning experiment class was given learning treatment by using cocoperative learning methods meanwhile control class was given learning by using problem based learning. Student ability in writing sklill is measure by questionnaire or test. Result of the research peove that student ability in writing who teach by cooperative learning methods same as the student who teach problem based learning. The T'test means that the null hypothesis accepted, there is no difference in the ability of the initial writing of the experimental class and the control class. Some difficulties of students; lack of vocabulary, can't write content is well, hard to understand the topic, hard to answer the question, and still nervous during discussion. To solve the problems like that the teacher can be a solution.
\end{abstract}

Keywords: Cooperative Learning Methods, Problem Based Learning, Writing

\section{INTRODUCTION}

Language is used by the people to make a communication. Without a language the people cannot communicate with other because language is an asset to communicate cannot be separate in our live. In modern Era as right now, students are expected to be able to communicate in English. One of ways of communication is writing, the students asked to master this skill as a tool to assess their knowledge. There are four skills which are necessary to be mastered by the learners of English. Those skills are listening, speaking, reading, and writing. Writing is one of the most difficult skills to be mastered. It is because writing involves some components (spelling, language in use, vocabulary and punctuation). Writing involves several components which have to be considered including word choice, use of appropriate grammar, syntax, mechanics, and organization of ideas into coherent and cohesive form, Gebhard (1996) as cited in Yulianti , Nuraeni \& Parmawati (2019).Writing needs hard thinking to produce ideas, words, sentences and paragraph. Some students still have difficulties to write in English especially write about their experience. Personal letter is a communication tool to express ideas in written form. Personal letter become the communication tool to convey information or ides in written form by one person to another.

Furthermore, communication can be delivered by using at least two ways, they are speech and written. In conclusion, writing skill is a skill that combine some language competence, such as grammar and vocabulary. This cooperative learning system can also be called similar to 
conventional learning methods. In cooperative learning methods the teacher provides information in the same direction, but the difference is after the teacher explains the material, students are asked to discuss by forming a junior high school group. Information is obtained not only from the teacher but also from material and also discussions with friends. Cooperative Learning Method is a learning method with junior high school groups of students and builds conducive learning conditions. The purpose of this cooperative learning method, namely, to improve academic learning outcomes, teach students to accept diversity and diversity, Develop social skills.

Problem-Based Learning (PBL) is a teaching method in which complex real-world problems are used as the vehicle to promote student learning of concepts and principles as opposed to direct presentation of facts and concepts. In addition to course content, PBL can promote the development of critical thinking skills, problem-solving abilities, and communication skills. According to Heaton (1988), "the writing skills are complex and sometimes difficult to teach, requiring $\mathrm{m} 20$ judgments elements". Writing as one of four language skills is considered as a difficult skill because the researcher should make some aspects in writing such as content, organization, purpose, vocabulary, punctuation, and spelling in a balance way. Based on the explanation above, it can be concluded that writing is a tool of communication to express feelings and thoughts. Oshima and Hogue (2007) mention that the steps of writing are Prewriting, Organizing, Writing, and Publishing: Revising and Editing. Pre- writing, In this step the researcher chooses a topic and collect ideas to explain the topic. Organizing, The next step in writing process is organizing the ideas into the simple outline. Writing, In this step the researcher writes a rough draft, using the outline as a guide. Publishing, In this step the researcher revise and edit what have been written. Normally, this step consists of editing and revising. For that reason, writing is difficult to be acquired by students (Alwasilah, 2001, cited in Apsari, 2018).

Cooperative learning is the one of the best researches of all teaching strategies. There are many kinds of cooperative learning which are can be applied to teach students, they are: Jigsaw, Team,Pair,Solo, Numbered Head, Small Group Discussion, Think-Pair-Share. Problem-based learning is a technique of learning where the students learn about the subjects through conceptual problem solving mechanisms. It is open ended in nature, and can be used by a wide number of students at the same time. According to Barrow, problem based learning is the learning that results from the process of working towards the understanding of a resolution of aproblem. The problem is encountered first in the learning process. According to Duch, PBL is an instructional method that challenges students to "learn to learn," working cooperatively in groups to seek solutions to real world problems. These problems are used to engage students' curiosity and initiate learning the subject matter. PBL prepares students to think critically andanalytically, and to find and use appropriate learning resources. Based on the some definition above, can concluded that problem based learning is a learning method which stimulate the students how to get information and solve the problem. The problem is encountered first in the learning process. According to (Harni, at.al. 2016) they said that "a personal letter is also called as a private letter and contains of private information about experience in the written form to be sent in a certain people". According to (Farid 2012) he said that there are many types of personal letters, and they are written for a wide variety of reason. And personal letters also known as friendly letters. Letter is a statement, which is written on a piece of paper or more. It contains feeling expression, private thing, and important thing. According to (Farid 2012) personal letters has function as written form communication, documentation, historical, reminder, 30 guidelines to take decision, safety information, vice of 
organization, as a way to easy the archival matters work and announcement, the main parts of personal letter consist of heading, salutation, body of letter, closing and signature.

\section{METHOD}

This research used quasi-experimental research design by using pretest and posttest with quatitative approach. Quantitative approaches are usually used to test one theory, to present a fact or describe statistics, to show relationships between variables, and some are developing concepts. In quantitative research is divided into experimental research, descriptive correlational, evaluation and so forth. The researchers may use methods of data collection such as, questionnaire or test. It should be noted that all the methods of data collection should objective. In this investigation, an objective test was used to obtain the scores of writing using personal letter. Instrument is a kind of tool used by researcher to collect the answer of getting data. The researcher uses test as an instrument to collect the data in this research. (Arikunto 2013) states that tests is the way to measure the ability, knowledge and intelligences from an individual or group. In this research, the researcher uses pre-test and post-test in getting the data. Population (target group) used in a questionnaire or interview study is that group about which the researcher is interested in gaining information and drawing conclusion (Truckman 1978). (Saleh 2001) states that population is a group of people or objects whose conditions are going to be discovered through the investigation.In this study, the writer decided to choose the eleventh graders of SMA Sebelas Maret, Bandung in the academic year of 2018/2019 as the population. They are three classes each class consists $30-32$, so the total population is 92 students. "Sample is the smaller group which is a portion of a population" (Tavakoli and Howard 2012). The writer choose one class, namely class XI IIS.1 (30 students), so the sample is 30 students. As stated above, the total populations of this research are 92 students. Thus, a conclusion is drawn that the sample are 30 students.

\section{RESULTS AND DISCUSSION}

\section{Results}

The following is a table of the result of the acquisition of the pretest and posttest score were performed on :

Table 4.1 The Score Result of Pretest and Posttest

\begin{tabular}{clcc}
\multirow{2}{*}{ NO } & Student's Name & \multicolumn{2}{c}{ Score } \\
\cline { 3 - 4 } & & Pretest & Posttest \\
\hline 1 & Student 1 & 60 & 70 \\
\hline 2 & Student 2 & 45 & 75 \\
\hline 3 & Student 3 & 45 & 60 \\
\hline 4 & Student 4 & 80 & 95 \\
\hline 5 & Student 5 & 75 & 85 \\
\hline 6 & Student 6 & 75 & 100 \\
\hline 7 & Student 7 & 60 & 75 \\
\hline 8 & Student 8 & 50 & 65 \\
\hline 9 & Student 9 & 50 & 90 \\
\hline 10 & Student 10 & 75 & 80 \\
\hline 11 & Student 11 & 75 \\
\hline 12 & Student 12 & 55 & 75 \\
\hline 13 & Student 13 & 50 & 65
\end{tabular}




\begin{tabular}{llll}
15 & Student 15 & 35 & 60 \\
\hline 16 & Student 16 & 55 & 60 \\
\hline 17 & Student 17 & 55 & 70 \\
\hline 18 & Student 18 & 45 & 70 \\
\hline 19 & Student 19 & 50 & 80 \\
\hline 20 & Student 20 & 60 & 85 \\
\hline 21 & Student 21 & 65 & 80 \\
\hline 22 & Student 22 & 50 & 60 \\
\hline 23 & Student 23 & 60 & 75 \\
\hline 24 & Student 24 & 55 & 75 \\
\hline 25 & Student 25 & 45 & 90 \\
\hline 26 & Student 26 & 45 & 70 \\
\hline 27 & Student 27 & 50 & 60 \\
\hline 28 & Student 28 & 40 & 60 \\
\hline 29 & Student 29 & 75 & 90
\end{tabular}

The pretest was conducted when the first researcher come in the class. While the posttest was conducted the last.

Tests of Normality

\begin{tabular}{|l|l|r|r|r|r|r|r|}
\hline & \multirow{2}{*}{$\begin{array}{l}\text { Pretest } \\
\text { Writing }\end{array}$} & \multicolumn{2}{|c|}{ Kolmogorov-Smirnov $^{\text {a }}$} & \multicolumn{3}{|c|}{ Shapiro-Wilk } \\
\cline { 2 - 8 } & \multicolumn{1}{c|}{$\begin{array}{c}\text { Statisti } \\
\text { Experimen }\end{array}$} & \multicolumn{1}{c|}{ Df } & \multicolumn{1}{c|}{ Sig. } & Statistic & \multicolumn{1}{c|}{ df } & \multicolumn{1}{c|}{ Sig. } \\
\hline $\begin{array}{l}\text { Pretest } \\
\text { kemampua } \\
\text { n writing }\end{array}$ & Control & 30 & .026 & .927 & 30 & .041 \\
& .174 & 32 & .015 & .937 & 32 & .062 \\
\hline
\end{tabular}

The table above shows the pretest ability in writing for the experiment that the kolmogorovsmirnov test pretest value ( $\mathrm{Sig}$ ) is 0.026 and for control pretest value (Sig) is 0.015 . Both of the results are more than 0.05. so the data can be called normal, and data the next homogenity varians test.

\section{Homogenity Varians Test of Experiment Group and Control Group}

\section{Table 4.5}

Test of Homogeneity of Variance

\begin{tabular}{|ll|r|r|r|r|}
\hline & & $\begin{array}{r}\text { Levene } \\
\text { Statistic }\end{array}$ & \multicolumn{1}{c|}{ df1 } & \multicolumn{1}{c|}{ df2 } & \multicolumn{1}{c|}{ Sig. } \\
\hline Pretest & Based on Mean & .461 & 1 & 60 & .500 \\
kemampuan & Based on Median & .354 & 1 & 60 & .554 \\
writing & Based on Median and & .354 & 1 & 58.707 & .554 \\
& with adjusted df & & & 60 & .527 \\
& Based on trimmed mean & .405 & 1 & 60 \\
\end{tabular}


The table above shows that the writing ability pretest contained in the experimental class and the control class both had homogeneous variances because the value of $\mathrm{p}$ (or $\mathrm{sig}=0.500$ ) was greater than 0.05. after the data is declared homogeneous, then the data requires a t-test.

\section{T-Test of Experiment Group and Control Group}

Table 4.6

Independent Samples Test

\begin{tabular}{|c|c|c|c|c|c|c|c|c|c|}
\hline & \multicolumn{2}{|c|}{\begin{tabular}{|c|} 
Levene's \\
Test for \\
Equality of \\
Variances \\
\end{tabular}} & \multicolumn{7}{|c|}{ t-test for Equality of Means } \\
\hline & \multirow[b]{2}{*}{$\mathrm{F}$} & \multirow[b]{2}{*}{ Sig. } & \multirow[b]{2}{*}{$\mathrm{t}$} & \multirow[b]{2}{*}{ df } & \multirow{2}{*}{$\begin{array}{l}\text { Sig. } \\
(2- \\
\text { tailed } \\
\quad)\end{array}$} & \multirow{2}{*}{$\begin{array}{c}\text { Mean } \\
\text { Differe } \\
\text { nce } \\
\end{array}$} & \multirow{2}{*}{$\begin{array}{c}\text { Std. } \\
\text { Error } \\
\text { Differen } \\
\text { ce }\end{array}$} & \multicolumn{2}{|c|}{$\begin{array}{c}95 \% \\
\text { Confidence } \\
\text { Interval of the } \\
\text { Difference } \\
\end{array}$} \\
\hline & & & & & & & & Lower & Upper \\
\hline $\begin{array}{ll}\text { Pretest } & \text { Equal } \\
\text { kemam } & \text { variances } \\
\text { puan } & \text { assumed } \\
\text { writing } & \text { Equal } \\
& \text { variances not } \\
& \text { assumed }\end{array}$ & .461 & $\begin{array}{r}.50 \\
0\end{array}$ & $\begin{array}{r}5.94 \\
0 \\
\\
5.92 \\
0\end{array}$ & $\begin{array}{r}58.3 \\
52\end{array}$ & .000 & $\begin{array}{r}17.364 \\
58 \\
\\
17.364 \\
58\end{array}$ & 2.93325 & $\begin{array}{r}11.51 \\
696 \\
\\
11.49 \\
379\end{array}$ & $\begin{array}{c}23.212 \\
21 \\
\\
23.235 \\
38\end{array}$ \\
\hline
\end{tabular}

Sig $=.0500>0.05$ then $\mathrm{Ho}=$ Accepted

That means :

There is no difference in the ability of the initial writing of the experimental class and the control class.

Table 4.2

The Score Result of the Sample Control Group

\begin{tabular}{clcc}
\multirow{2}{*}{ NO } & Student's Name & \multicolumn{2}{c}{ Score } \\
\cline { 3 - 4 } & & Pretest & Posttest \\
\hline 1 & Student 1 & 55 & 65 \\
\hline 2 & Student 2 & 30 & 65 \\
\hline 3 & Student 3 & 15 & 30 \\
\hline 4 & Student 4 & 45 & 65 \\
\hline 5 & Student 5 & 35 & 70 \\
\hline 6 & Student 6 & 55 & 75 \\
\hline 7 & Student 7 & 70 & 75 \\
\hline 8 & Student 8 & 40 & 80 \\
\hline 9 & Student 9 & 50 & 65 \\
\hline 10 & Student 10 & 30 & 75
\end{tabular}




\begin{tabular}{llll}
11 & Student 11 & 35 & 60 \\
\hline 12 & Student 12 & 30 & 50 \\
\hline 13 & Student 13 & 30 & 40 \\
\hline 14 & Student 14 & 40 & 50 \\
\hline 15 & Student 15 & 35 & 50 \\
\hline 16 & Student 16 & 40 & 55 \\
\hline 17 & Student 17 & 30 & 55 \\
\hline 18 & Student 18 & 25 & 55 \\
\hline 19 & Student 19 & 40 & 55 \\
\hline 20 & Student 20 & 45 & 50 \\
\hline 21 & Student 21 & 45 & 60 \\
\hline 22 & Student 22 & 45 & 65 \\
\hline 23 & Student 23 & 50 & 65 \\
\hline 24 & Student 24 & 30 & 50 \\
\hline 25 & Student 25 & 30 & 65 \\
\hline 26 & Student 26 & 40 & 60 \\
\hline 27 & Student 27 & 30 & 55 \\
\hline 28 & Student 28 & 45 & 40 \\
\hline 29 & Student 29 & 30 & 55 \\
\hline 30 & Student 30 & 30 & 55 \\
\hline 31 & Student 31 & 40 &
\end{tabular}

Tests of Normality

\begin{tabular}{|c|c|c|c|c|c|c|c|}
\hline & \multirow[b]{2}{*}{$\begin{array}{l}\text { Posttest } \\
\text { Writing }\end{array}$} & \multicolumn{3}{|c|}{ Kolmogorov-Smirnov $^{\mathrm{a}}$} & \multicolumn{3}{|c|}{ Shapiro-Wilk } \\
\hline & & $\begin{array}{c}\text { Statisti } \\
\mathrm{c} \\
\end{array}$ & df & Sig. & Statistic & df & Sig. \\
\hline Posttest & Experimen & .112 & 30 & $.200^{*}$ & .938 & 30 & .081 \\
\hline $\begin{array}{l}\text { kemampua } \\
\text { n writing }\end{array}$ & Control & .124 & 32 & $.200^{*}$ & .967 & 32 & .414 \\
\hline
\end{tabular}

The table above shows the posttest ability in writing for the experiment that the kolmogorovsmirnov test posttest value (Sig) is 0.200 and for control posttest value ( $\mathrm{Sig}$ ) is 0.200 . Both of the results are more than 0.05 . so the data can be called normal, and data the next homogenity varians test. 
1. Homogenity Varians Test of Experiment Group and Control Group

Table 4.9

Test of Homogeneity of Variance

\begin{tabular}{|ll|r|r|r|r|}
\hline & \multicolumn{1}{|c|}{$\begin{array}{c}\text { Levene } \\
\text { Statistic }\end{array}$} & \multicolumn{1}{c|}{ df1 } & \multicolumn{1}{c|}{ df2 } & \multicolumn{1}{c|}{ Sig. } \\
\hline Posttest & Based on Mean & .000 & 1 & 60 & .997 \\
kemampuan & Based on Median & .003 & 1 & 60 & .959 \\
writing & Based on Median and & .003 & 1 & 59.915 & .959 \\
& with adjusted df & & & \\
& Based on trimmed mean & .001 & 1 & 60 & .970 \\
\hline
\end{tabular}

The table above shows that the writing ability posttest contained in the experimental class and the control class both had homogeneous variances because the value of $p$ (or $\operatorname{sig}=0.997$ ) was greater than 0.05 . after the data requires a t-test.

\section{T-Test of Experiment Group and Control Group}

Table 4.10

Independent Samples Test

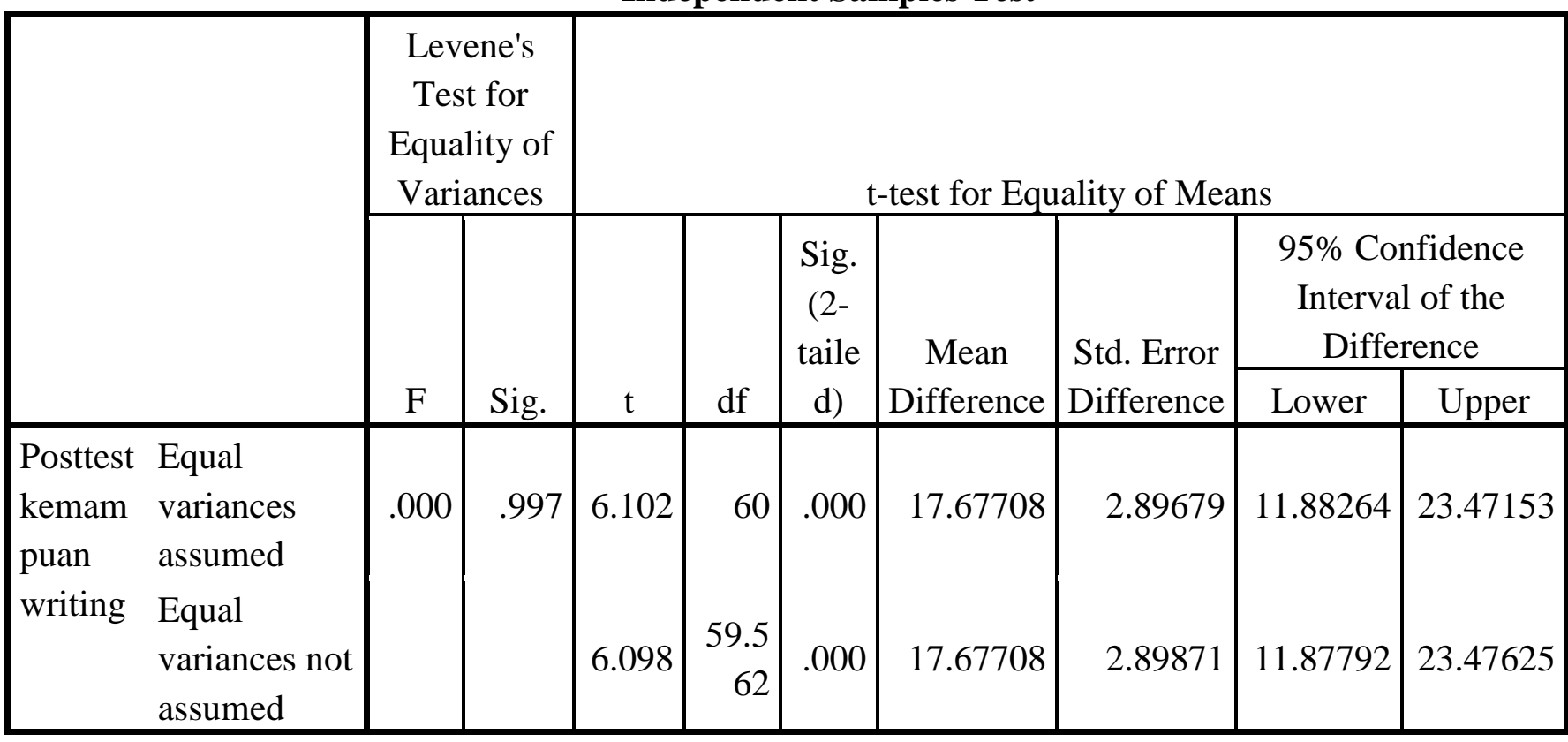

Sig $=.0997>0.05$ then $\mathrm{Ho}=$ Accepted

That means :

There is no difference in the ability of the initial writing of the experimental class and the control class.

\section{Discussion}

The result pretest above shows that cooperative learning methods better than problem based learning. The data from this study has been shown quantitatively. The activities of this study were done, there are pretest, the teaching, and learning using cooperative learning methods and 
problem based learning (the treatments), the posttest, the analysis of the result from the test. The students were asked 11 questions, 10 multiple choice and 1 essay, at the first meeting related to the main idea, statements, word meaning, and inferences before any treatment being done. After the questions have been answered the pretest began. Then, in the next meeting after conducting the pretest the next was talked and explained clearly by the teacher and researcher as the treatment.

The teacher used the problem based learning to students in control group for teaching writing personal letter. To know the achievement and improvement of both groups, the writer was analyzed the score posttest from experiment class and control class. The means score of the posttest result for both the experiment class and control class were also calculated. The procedure analysis was the same as the pretest. The posttest score for the experiment is 0,200 and control class with the same of the result, class was 0,200. The variances in the result were tested and presented that the result of both groups was normally distributed. The T-test presented there was not difference in the ability of the initial writing of the experimental class and the control class. However, some students still got the difficult during the treatments such as some students said that "I'm understand what do you say, but I'm not the answer again", in other words students lack of confidence. The others share their problem on lack vocabulary, can't write the content well, hard to understand the topic, hard to answer the question, and still anxiety or nervous during discussing. Another problem there were several students which active during discussion and the others just keep quite. To solve the problems like that the teacher can be a solution. The teacher will lead, and guide the learning process by using cooperative learning methods and problem based learning.

\section{CONCLUSION}

Result of the research prove that the students' ability in writing who teach by cooperative learning methods same as student who teach by problem based learning. The T'test means that the null hypothesis accepted, there is no difference in the ability of the initial writing of the experimental class and the control class. Some difficulties of students; lack of vocabulary, can't write content is well, hard to understand the topic, hard to answer the question, and still nervous during discussion. To solve the problems like that the teacher can be a solution.

\section{ACKNOWLEDGMENTS}

We thank the family who have given us support both morally and materially, so that we can complete and publish our article.

\section{REFERENCES}

Apsari, Y. (2018). Reflective Reading Journal In Teaching Writing. Indonesian Efl Journal, 4(2), 39-47.

Arikunto, Suharsimi. 2013. Prosedur Penelitian: Suatu Pendekatan Praktik. Jakarta: Rineka Cipta. 
Farid, Helmi. 2012. "Improving Students' Skill In Writing Recount Text By Using A Personal Letter." 10.

Harni And At.Al. 2016. "Developing Writing Skill Of Grade Viii Students Through Personal Letter." E-Journal Of Elts 4(1):3.

Heaton, J. B. 1988. Writing English Language Tests. New York: Longman.

Oshima, Alice And Ann Hogue. 2007. Introduction In Academic Writing. New York: Pearson Education.

Saleh, Abdul Rahman. 2001. Pemberdayaan Perpustakaan Perguruan Tinggi.

Tavakoli, P. And M. .. Howard. 2012. “Tesol Teachers' Views On The Relationship Between Research And Practice.” European Journal Of Teacher Education 35(2):229-43.

Truckman, Bruce W. 1978. Conducting Educational Research. San Diego: Harcourt Brace Jovanovich.

Yulianti, S., Nuraeni, S., \& Parmawati, A. (2019). Improving Students'writing Skill Using Brainswriting Strategy. Project (Professional Journal Of English Education), 2(5), 714721. 